Bangladesh Journal of Anatomy January 2010, Vol. 8 No. 1 pp. 16-20

\title{
Role of Flutamide on Testosterone Induced Prostatic Hyperplasia in Long Evans Rats
}

\author{
Md. Atiar Rahman ${ }^{1}$, Humaira Naushaba², Jesmin Akter ${ }^{3}$, Uttam Kumar Paul ${ }^{4}$, Nahid Ahmed Khan ${ }^{5}$, \\ Nashid Rahman ${ }^{6}$
}

\begin{abstract}
Context: Testosterone is the male sex hormone responsible for growth of secondary sexual character and accessory sex organs. Despite the effectiveness as a male sex hormone, testosterone causes Benign Prostatic Hyperplasia $(\mathrm{BPH})$ resulting in urinary dysfunction. On the other hand, flutamide is a pure antitestosterone, which blocks the effects of Dihydro testosterone (DHT) at the testosterone receptor and prevents $B P H$. Therefore the present study was designed to observe the protective role of flutamide on testosterone induced prostatic hyperplasia.
\end{abstract}

Objective: To observe the effects of flutamide on testosterone induced prostatic hyperplasia in Long Evans rats.

Study design: An experimental study.

Place and period of study: The study was carried out in the Department of Anatomy, Sir Salimullah Medical College, Dhaka during the period of July 2006 to June 2007.

Materials \& Methods: Forty five matured male long Evans rats of age 8-10 weeks and weighing 200-300 gms were used in this study. They were divided into three equal groups. Group A was vehicle (olive oil) control group, Group B was testosterone treated group and Group C was testosterone \& flutamide treated group. Comparative study in different groups were done microscopically.

Results: There was significant reduction $(P<0.001)$ in prostatic hyperplasia. The mean percentage volume of stroma in flutamide treated rats was lower than the testosterone treated rats.

Conclusion: It can be concluded from this study that flutamide is an effective drug against testosterone induced prostatic hyperplasia.

Key words: Prostate, Testosterone, Flutamide.

\section{Introduction:}

The prostate is an accessory gland of male reproductive system that surrounds the neck of male

1. Associate Professor, Department of Anatomy, Holy Family Red Crescent Medical College, Dhaka.

2. Professor and Head, Department of Anatomy, Sir Salimullah Medical College, Dhaka.

3. Assistant Professor (c.c.), Department of Anatomy, Ibrahim Medical College, Dhaka.

4. Assistant Professor (c.c.), Department of Anatomy, Sir Salimullah Medical College, Dhaka.

5. Lecturer, Department of Anatomy, Holy Family Red Crescent Medical College, Dhaka.

6. Lecturer, Department of Biochemistry, Holy Family Red Crescent Medical College, Dhaka.

Correspondence: Dr. Md. Atiar Rahman urinary bladder and the proximal portion of the urethra. The prostate consists of branched tubuloacinar glands embedded in a fibromuscular stroma ${ }^{1}$. Clinically, prostate is an important pelvic organ for its affinity to diseases like benign prostatic hyperplasia. Testosterone is responsible for development of accessory sex organs and secondary sexual characteristics ${ }^{2}$. In the target tissue, testosterone is not the active form of the hormone, it is reduced to dihydrotestosterone (DHT) by an enzyme $5, \alpha$-reductase and is 10 times more potent than testosterone because it dissociates from the cellular testosterone receptor more slowly ${ }^{3,4}$. 
Growth of the prostate, normal and abnormal is mediated by testosterone. Benign Prostatic Hyperplasia (BPH) is a non-malignant enlargement of prostate gland that commonly develops in the aging male. It is a hyperplastic process of the stroma and epithelial tissues of the prostate gland. DHT binds to cytoplasmic receptor protein, forming complex then migrates to the nucleus and binds to the nuclear testosterone receptor and induces the DNA-RNA transcription process which is mitogenic and leads to hyperplasia of the target organ ${ }^{4}$.

Flutamide is a pure antitestosterone without significant progestogenic actions which blocks the effects of DHT at the testosterone receptor and prevents $(\mathrm{BPH})^{5,6}$. Mechanism of action of flutamide is the competition with testosterone for the testosterone receptor ${ }^{7}$. Flutamide is an effective drug in the treatment of $\mathrm{BPH}$, which reduces hyperplasia of the prostate rapidly ${ }^{8}$.

Materials \& method:

Forty five adult male rats of Long Evans strain weighing between $200-300$ gms of age 8-10 weeks were used in the present study. All the rats were divided into three groups and were sacrificed on the eleventh day of study by decerebration under ether anesthesia.

Group A: Served as the vehicle control group and comprised of 15 rats, each rat received an injection of $0.2 \mathrm{ml}$ of olive oil (vehicle) daily for 10 days.
Group B: Served as the testosterone control group and comprised of 15 rats, each rat received $0.32 \mathrm{mg}$ testosterone propionate in $0.01 \mathrm{ml}$ of suspension daily subcutaneously for 10 days.

Group C: Served as the flutamide treated rats and comprised of 15 rats, each rat received $0.32 \mathrm{mg}$ testosterone propionate in 0.01 $\mathrm{ml}$ of suspension and flutamide $2.00 \mathrm{mg}$ in $0.08 \mathrm{ml}$ of suspension daily subcutaneously for 10 days.

\section{Procedure for preparing histological sections:}

Out of fifteen (15) prostates in each group, histological studies were carried out on 6 randomly selected specimens.

The ventral prostate was fixed in $10 \%$ formal saline solution and processed following routine histological procedure. The tissues were dehydrated in ascending concentration of alcohol, cleared in xylene, infiltrated and embedded in paraffin. Sections of the tissues of $6 \mathrm{~mm}$ (micrometer) thickness were made by a rotary microtome and were stained with haematoxylin and eosin (H\&E).

Estimation of the stroma in the ventral prostate was done at low power field (X10 objectives $\times 10$ eyepiece) of microscope:

The proportion of structural stroma of prostate were determined by using a 'Point Counting technique'. A replica of Zeiss integrating eyepiece was prepared

Table-I

Grouping of animals, doses of drugs and sacrifice schedule

\begin{tabular}{|c|c|c|c|c|c|c|c|}
\hline Groups & $\begin{array}{c}\text { No. } \\
\text { of } \\
\text { rats }\end{array}$ & $\begin{array}{l}\text { Feeding } \\
\text { status }\end{array}$ & Drug & $\begin{array}{c}\text { Dose/kg/ } \\
\text { body wt }\end{array}$ & $\begin{array}{c}\text { Dose rat/ } \\
\text { day }\end{array}$ & $\begin{array}{c}\text { Duration of } \\
\text { administration } \\
\text { (in days) }\end{array}$ & $\begin{array}{c}\text { Day of } \\
\text { sacrifice } \\
\text { (in days) }\end{array}$ \\
\hline $\bar{A}$ & 15 & $\begin{array}{l}\text { Normal } \\
\text { food and } \\
\text { water }\end{array}$ & Vehicle & & $0.2 \mathrm{ml}$ & 10 & 11 \\
\hline$B$ & 15 &, & Testosterone & $1.6 \mathrm{mg}$ & $0.32 \mathrm{mg}$ at $0.01 \mathrm{ml}$ & 10 & 11 \\
\hline C & 15 & , & $\begin{array}{c}\text { Testosterone } \\
+ \\
\text { Flutamide }\end{array}$ & $\begin{array}{l}10 \mathrm{mg} \\
+ \\
1.6 \mathrm{mg}\end{array}$ & $\begin{array}{c}0.32 \mathrm{mg} \text { at } 0.01 \mathrm{ml} \\
+ \\
2 \mathrm{mg} \text { at } 0.08 \mathrm{ml}\end{array}$ & 10 & 11 \\
\hline
\end{tabular}


with a transparent plastic sheet and was placed into the eyepiece. The Zeiss eyepiece contains a graticule of 25 points. Visual of the slide was divided into eight equal parts by drawing four lines on the coverslip. The counting was done under light microscope in low magnification in slides stained with routine haematoxylin and eosin stain. At a low magnification, using an X10 objective and an X10 eyepiece, the position of each point on the graticule, falling on stroma of prostatic slide, in the inter-acini space. Thus, taking 25 points on the graticule for each field, a total of $200(25 \times 8)$ point position were recorded for each slide (Elias and Hyde, 1980).

The total number of points hitting inter-acinus prostatic stroma was summed up and expressed as a percentage of the total number of points.

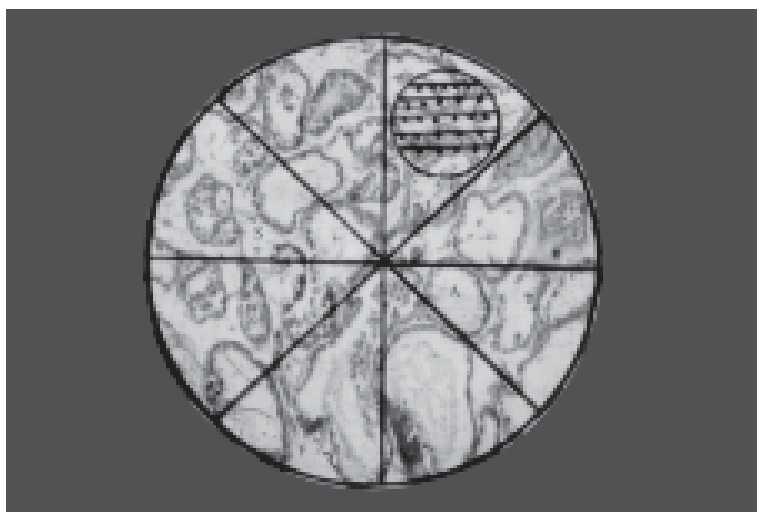

Fig.-1: Photomicrograph showing procedure of measuring the percentage of stroma in prostate of rat.

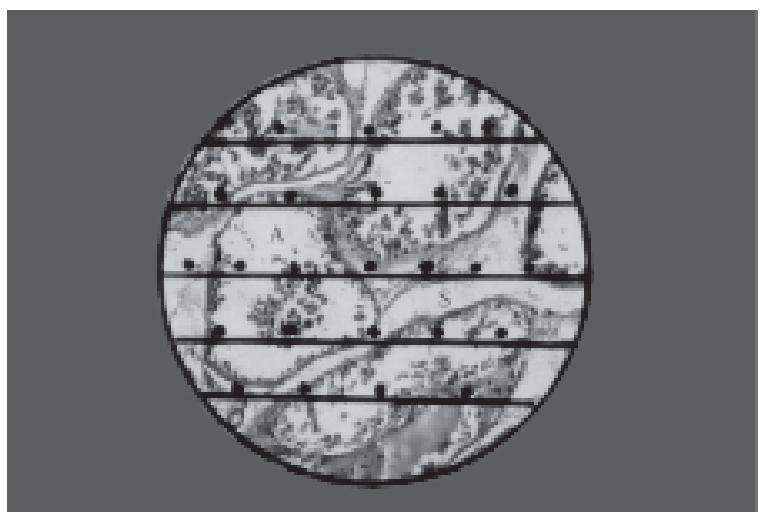

Fig.-2: Photomicrograph showing procedure of estimation of the percentage of stroma in prostate of rats by Zeiss integrating eyepiece (after Elias and Hyde, 1980)

\section{Results:}

Table-II \& Figure-3, 4, 5, 6 shows the percentage volume of stroma between different groups of rats. The mean percentage volume of stroma in the vehicle control (Group A) rats was $14.83 \pm 1.78$. The mean percentage volume in the testosterone treated (Group B) was $20.25 \pm 0.69$ was higher than the vehicle treated rats. The mean percentage volume of stroma in flutamide treated group (Group C) was $15.00 \pm 0.71$. The value of this group was lower than that of testosterone treated rats. The mean difference was highly significant $(P<.001)$ when compared between the groups.

Table-II

Comparison of percentage of stroma between different groups of rats $(n-6)$

\begin{tabular}{lcc}
\hline & \multicolumn{2}{c}{ Stroma (\%) } \\
\cline { 2 - 3 } Groups & Range & Mean \pm SD \\
\hline A (Vehicle control) & $12.5-17.5$ & $14.83 \pm 1.78$ \\
B (Testosterone-treated & $19.0-21.0$ & $20.25 \pm 0.69$ \\
control) & & \\
C (Testosterone + & $14.0-16.0$ & $15.00 \pm 0.71$ \\
Flutamide-treated) & & \\
\hline
\end{tabular}

$\begin{array}{ll}\text { A vs } B & P<0.001 \text { significant) } \\ \text { A vs C } & P<0.50 \text { (non significant) } \\ \text { B vs C } & P<0.001 \text { (significant) }\end{array}$

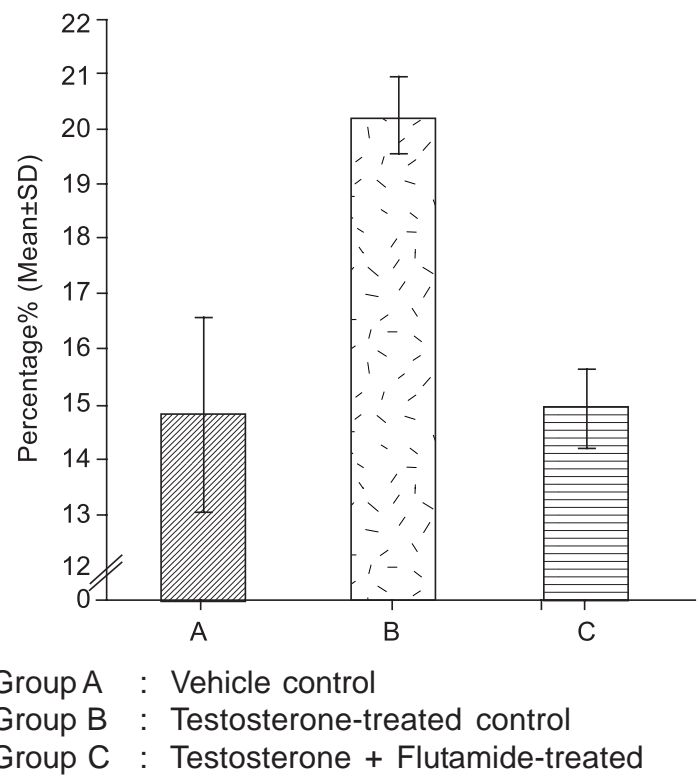

Fig.-3: Bar diagram showing the percentage of stroma in different groups of rats. 


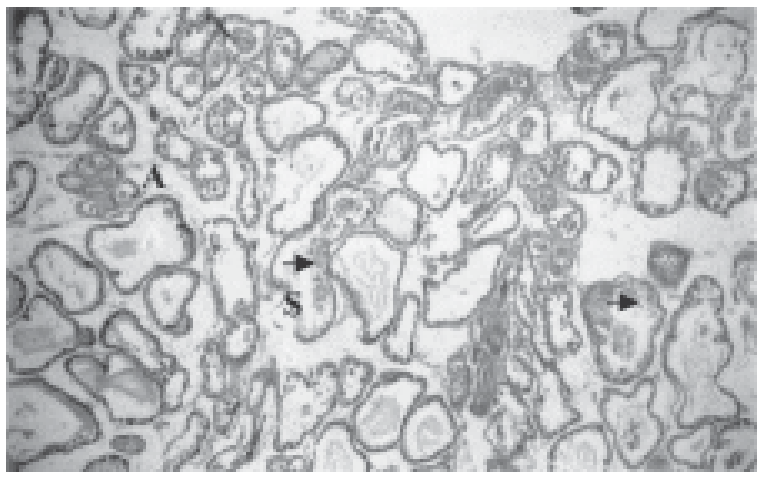

Fig.--4: A low power (X10 objective) photomicrograph showing prostatic tissue in vehicle control rat; acini (A), stroma (S), epithelium (arrow). H\&E stain.

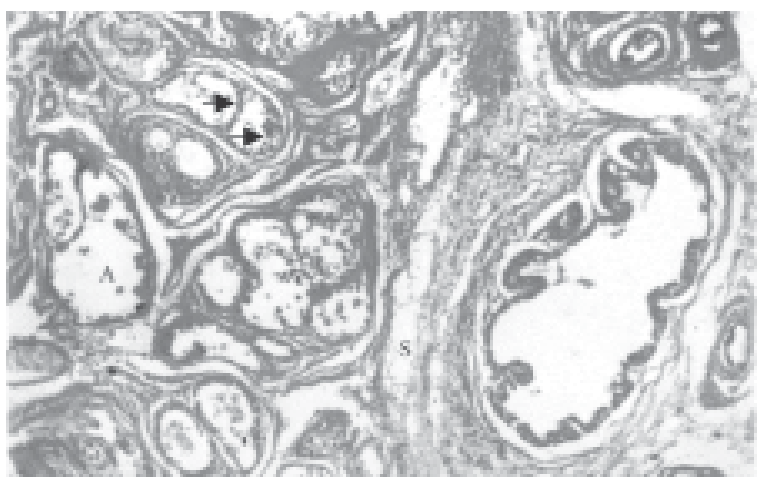

Fig.-5: A low power (X10 objective) photomicrograph showing hypertrophied prostatic tissue in testosterone-treated rat; acini (A), stroma (S), epithelium (arrow). H\&E stain.

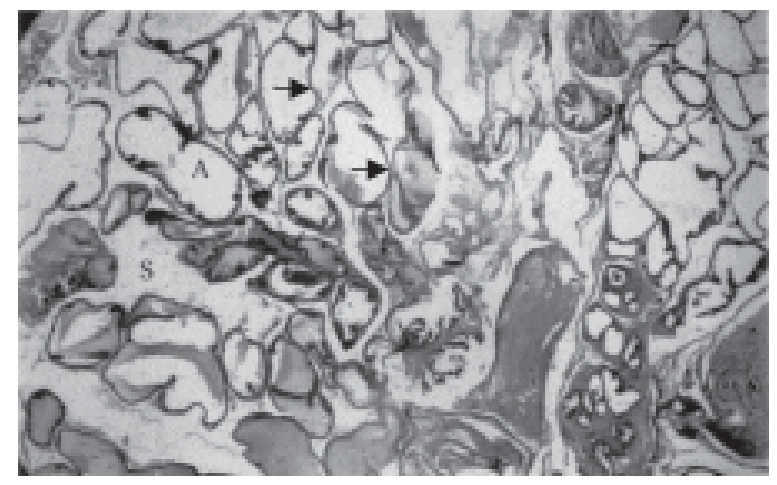

Fig.-6: A low power (X10 objective) photomicrograph showing atrophied prostatic tissue in testosterone plus flutamide-treated rat; acini (A), stroma (S), basement membrane (arrow). H\&E stain.

\section{Discussion:}

The increase in values were due to hyperplasia of the acini and the stroma of the prostate in testosterone treated rats. Shapiro et al ${ }^{10}$, Handlsman DJ. ${ }^{12}$ also stated that relative increase in proportion of stroma was related to the effects of testosterone on prostate. In flutamide treated rats the percentage volume of the stroma of the prostate was lower than that of testosterone treated rats and the difference was significant $(P<0.01)$. Similar results were reported by Wilson $\mathrm{JD}^{4}$, Niu YJ et al ${ }^{9}$.

\section{Concluding Remarks:}

Flutamide is a nonsteroidal antistestosterone used in the treatment of BPH \& prostatic cancer. It blocks the effects of DHT at the testosterone receptor. The trend of antitestosterone effect of flutamide against testosterone induced hyperplasia was observed in the present study.

\section{References:}

1. Bruchovsky N, Lesser B, Van Doom E, Cravens. Hormonal effects on cell proliferation in rat prostate. Vitam Horm 1975; 3: 61-102.

2. Davies P, Eaton CL. Regulation of prostate growth. J Endocrin 1991; 131: 5--17.

3. Elias $\mathrm{H}$, Hyde DM. An elementary introduction to stereology. Physiol Rev 1980; 412-23.

4. Wilson JD, Walsh PG. Recent studies on the mechanism of action of testosterone. $\mathrm{N}$ Engl J Med 1996; 21: 1284-94.

5. Labric F. Mechanism of action and pure antiandrogenic properties of flutamide. Cancer 1993; 72(2):3816-27.

6. Cordero RS, Scarano WR, Goes RM, Tabga $\mathrm{SR}$. Tissue alterations in the guinea pig lateral prostate following antiandrogen flutamide therapy. Biocell 2004; 28(1):21-30.

7. Goto K, Koizumi K, Ohta Y, Hashi M, Fujii Y, Ohbo N, et al. Rats treated with flutamide during late gestation. J Toxicol Sci 2005; 30(3):249-59.

8. Kang IH, Kim HS, Shin JH, Kim TS, Moon HJ, Kimly, et al. Comparison of antiandrogenic activity of flutamide, vinclozolin, procymidone and linuron. Toxicology 2004; 199(2-3):145-59. 
9. Niu YJ, Mz TX, Zhang J, et al. Androgen and prostatic stroma. Asian J Androl 2003; 5: 1926.

10. Shapiro E, Becich MJ, Hartanto MJ, Lepor H. The relative proportion of stromal and epithelial hyperlasia is related to the development of symptomatic benigh prostatic hyperplasis. J Urol 1992; 147: 1293-97.
11. Huttunen E, Romppanen, Helminen HJ. A histoquantitative study on the effects of castration on the rat ventral prostate lobe. $\mathrm{J}$ Anat 1981; 132: 357-70.

12. Handlsman DJ. Testosterone and other androgens. Endocrinology. $3^{\text {rd }}$ ed. Philadelphia: WB Saunders Company; 1995. p.2351-61. 